\title{
Financing Model Optimization of Lanzhou Yatai Group Real Estate Project
}

\author{
Haidong Feng \\ Faculty of Economics and Management, University of Latvia, Riga, Latvia
}

\begin{abstract}
Lanzhou Yatai Group, as the first listed real estate companies, occupies absolute advantage in the competition of the industry. Especially because of Lanzhou National Economic Development District, Yaitai Group focuses Lanzhou new area asthe target of the advantages and great location. With the business development and planning, the company will also create Lanzhou Yaitai Group Technology Headquarters before 2016, and also will be followed by the huge business opportunities in the real estate industry driven by the financial industry, service industry, catering industry, and the education industry as well. At the same time, the asset number of investment companies in the new district has reached about 0.45 billion, so the vast number of these channels also makes traditional financing be in danger. Banking loans, equity financing, debt financing gradually are difficult to enable the company's rapid development growing so fast. Large-scale funding and financing inefficiencies of some large-scale projects also make the company's financial operations meeting some obstacles. In this paper, the author will analyze Yatai Group real estate financing process and the traditional financing channels to predict its financing risk prevention and the Group's real estate funds operating characteristics of the project. At the same time, we put forward the concept and characteristics of the real estate project financing. After financing inefficiencies of Lanzhou Yatai Group from 2011 to 2014, we make the analysis for real estate projects for the company and make a selection and optimization models. But also for the smooth development of real estate projects in Yatai Group, we provided a positive recommendation, which will become healthy and stable developments of the real estate industry in Gansu Province, and the development and construction of new district will be made as a good expectation.
\end{abstract}

Keywords: Real estate companies, Project financing, Financing model, Risk prevention

\section{Introduction}

With the development of world economy and continuous improvement of management applications, increasing number of scholars are beginning to focus on project management (Chan A P C, Scott D, Lam E W M, 2002; Pheng L S, Leong C H Y, 2000; Deng Z M, Li H, Tam C M, 2001; Shen L Y, 1997), affecting factors of project management (Chan A P C, Scott D, Chan A P L, 2004; Chan A P C, Ho D C K, Tam C M, 2001) and the associated real estate projects (Veale P R., 1989; Ginevičius R, Zubrecovas V, 2009; Krumm P J M M, Dewulf G, De Jonge H, 1998). Besides, many scholars are concerned about the development of Chinese enterprise (Steinfeld E, 2004), especially small and micro enterprises in China (Anderson A R, Li J H, Harrison R T, et al., 2003; Gibb A, Li J, 2003), Chinese private enterprises (Chen W., 2007; Zhonghui W, 1990)and the Chinese collective enterprises (Tian G, 2000).

Over the last decade, China has experienced the rapid development of the real estate industry, and the average annual increase rate of the GDP is about $8 \%$. However, due to persistently high prices and overheated real estate market in recent years, the country has also changed the control of the intensity of macroeconomic policies and the implementation of real estate loans monetary tightening policies. To further promote the stability of the regional economic development, speeding up the development of stable housing prices is a crucial social problem. 
Lanzhou Yatai Group is the largest real estate company in a capital-intensive industry in Lanzhou, Gansu Province. The financing of the company's development is of huge significance, and also in the development of Lanzhou Economical New District project financing still faces many problems and risks. Therefore, enhancing the company's financing capacity, actively expanding the variety of new financing channels, optimizing various financing channels to avoid the risk of financing to solve current problems are the top priorities.

Since the 1980s, China's real estate industry began a rapid development, and the real estate industry has become China's economic development to support the industry. In the past few years, the growth is more than $20 \%$ in each year. According to statistics, China's real estate industry investment in 2006 reached 1.315829 trillion RMB, and sales area reached 382,316,800 square meters. The first quarter of 2006, real estate investment reached 182.7 billion RMB, which is an increase of $42.1 \%$. On the one hand, the investment in the real estate industry has reached a large amount risk earnings.

Also, the large source of investment has been focusing on the developers who pay close attention to the economy because it directly affects the construction problem of real estate projects. The external environment has forced Yatai Group to consider the issue of financing in profit optimization process. From another point of view, due to mature capital market, housing prices have been listed can make a choice from more financing, which makes the premise of more stable financing.

This article is under such conditions, expanding the optimization of Yatai Group financing channels and making the financing of enterprises in time to meet the company's capital needs, and it can also minimize the cost of the investment risk under the control of the premise. Housing prices in solving optimization problems of financing channels are the smooth conduct of the company's development projects. And it can promote the healthy and stable development of the industry in Gansu province as well. This is the practical significance of this paper.

\section{Real Estate Enterprises and Small and Medium Real Estate Companies}

Based on the factors of production, real estate business refers to the land, human, finance, etc. With the risk to carry out real estate development, real estate consulting provides management services, economies transfer of land use rights and other aspects of the business. From the definition of real estate corporate, it can be seen that the real estate market and the business of enterprise are more complicated, as long as the real estate business-related companies can be called the real estate business or real estate companies. Due to the number of real estate companies and more widely involved business, according to different criteria, real estate corporate can be divided into different categories. This paper defines the following two reference standard for the real estate business to be divided:

According to China State Council's State-owned Assets Supervision and Administration Commission, the National Bureau of Statistics 2008 reference principle, the latest standard criteria for the classification of companies was divided. Small and Medium Real Estate Companies (that own 300 or fewer employees in the real estate business, or total sales at 250 million RMB or below, or total assets of 500 million RMB or less. ) Large Enterprises (require both of the following conditions: more than 300 people and total sales of 250 million RMB and above.) As is shown in Table one below (Unit RMB):

Table1: Real Estate Business Classification Table

\begin{tabular}{|l|l|l|l|}
\hline Businesses Types & Total Sales & Numbers of Employees & Total Assets \\
\hline Small and Medium & $\begin{array}{l}\text { less than 250 million } \\
\text { more than or equal to 250 } \\
\text { million }\end{array}$ & less than 300 people & Less than 500 million \\
\hline Large & $\begin{array}{l}\text { more than or equal to 300 people } \\
500 \text { million and above }\end{array}$ \\
\hline
\end{tabular}

According to the new provisions of China in April 2007, in accordance with the Ministry of Construction, implementing the qualification grading criteria is in addition to the real estate enterprise engineering quality, results of 
operations, assurance system and professional and technical staff as well as the qualifications of the person responsible, engineering major accident the exact requirements. There is a clearly defined capital registration requirement of the occurrence rate. The first class enterprise is with registered capital of 60 million RMB; the second class company is 30 million RMB; the third is of 900 million RMB; the fourth class is of 150 million. Combined with the actual situation in the real estate business in the standard basis of a comprehensive analysis of the above two types, taking the total assets, total sales, business intelligence, and the number of employees as the basis for the division of real estate enterprises is necessary.

\section{Traditional Financing Overview of Yatai Group Real Estate Projects}

\subsection{Lanzhou Yatai Group Real Estate Project}

Lanzhou Yatai Group Real Estate Development Group is headquartered in Lanzhou City, Gansu Province, and it was established in 1998 with registered capital of 760 million RMB, and the total number of employees is 279 . The company always adheres to the "people-oriented" business philosophy. With anemphasis on the central position of the real estate industry, it has a very high value quality and progress of construction. And in the early days, the company was accumulated more than 4,000,000 square meters building area.

In support of the Lanzhou Municipal People's Government, Yatai Group real estate company took the investment of 10 billion RMB to further strengthen cooperation between government and enterprises. In 2012 the central government approved the construction of the fifth Lanzhou National Economic Development District, then Yatai Group will invest 2.5 billion RMB construction in Lanzhou Yatai technology headquarters, which covers an area of up to 1,300 acres; in second phase in which the project has standardized industrial plants, industrial incubator, high-tech parks and youth entrepreneurship zone cover an area of approximately 650 acres.

It has attracted a variety of research and development, production, business, entrepreneurship and service agencies. Financial operation of Yatai Group headquarters in Lanzhou New Technology Development Project is shown in Fig. 1.

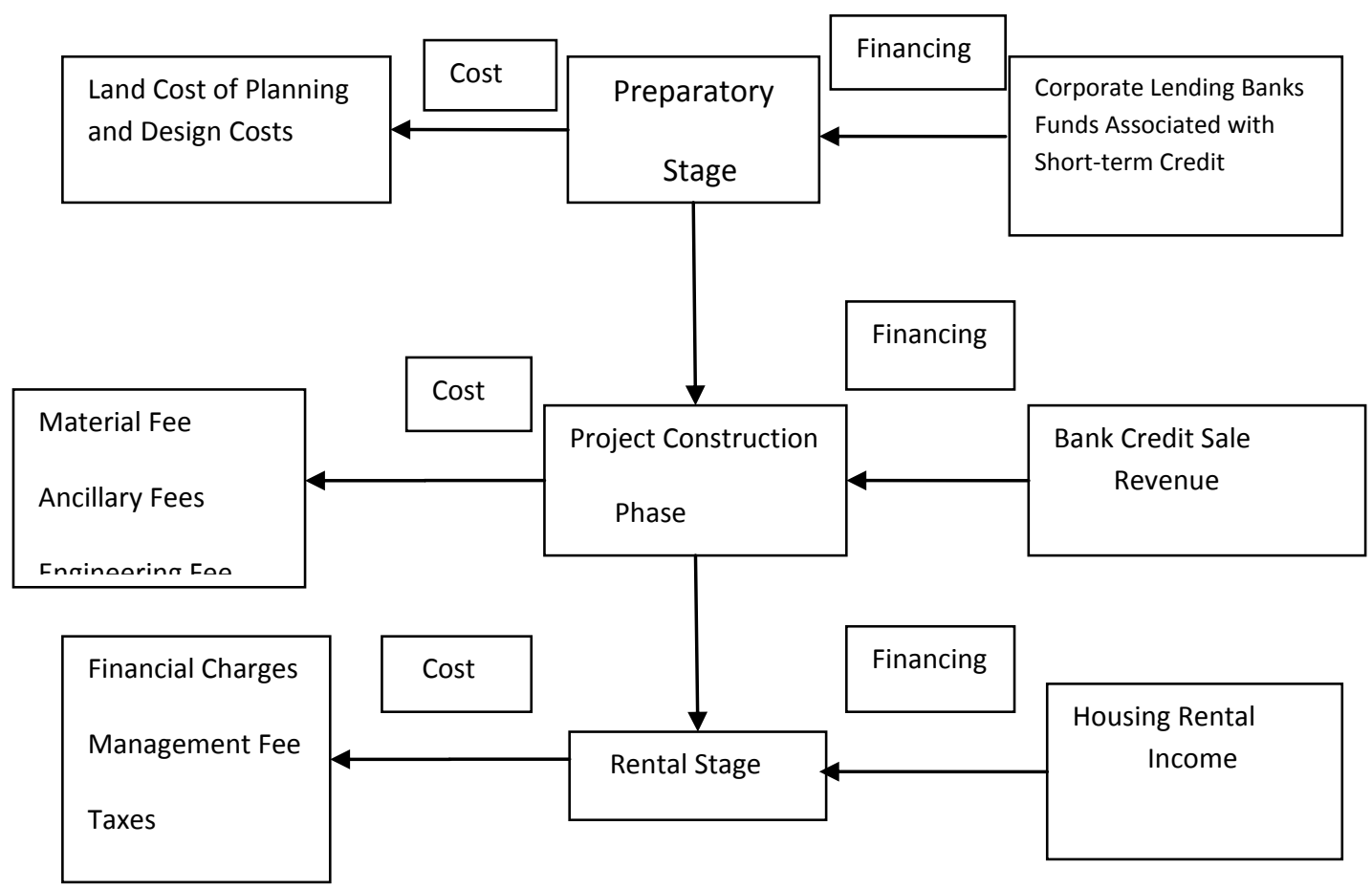

Figure 1: Financial Operation of Yatai Group Headquarters in New Technology Development Project Source: Authors construction 


\subsection{The Operational Funding Characteristics of Yatai Group}

Since its establishing in 1997, Yatai Group in Gansu province is in a leading position in real estate companies. And Real Estate Group, founded in 1998, gradually became capital-intensive enterprises. Real estate is a long payback period typically in the building industry as well as the late great potential value, so Yatai Group financial operations have the following characteristics:

\subsubsection{High Investment Costs}

The high cost of Yatai Group real estate development projects is on large capital investment. In thefirst quarter, 2010, the price of land transactions in Lanzhou city rose more than 11 percent, and Cheng Guan District of Lanzhou City Dong Gang Road, 276 acres of land, was acquired by Yatai Group in on February 2, 2010, with a total amount of 460 million. Meanwhile, the new project is located in the main area of Lanzhou industry functional area which is $4.6 \mathrm{~km}$ from the Lanzhou Airport, and the second phase of the project in the new district is expected to be 4.6 billion RMB, and it has been put into the building which covers an area of 450 acres of land. Group companies also cooperate with the municipal government to raise 2.5 billion for Lanzhou City Qin WangChuan residential buildings and the construction of affordable housing, with a total area of up to 320,000 square meters. So we can see the high cost investment.

\subsection{Long Payback Period}

Yatai International Group mansion in the initial design is due to the introduction of building in the design which was spent nearly a year's time. In this process, pre-qualification of construction units employ construction had already spent 30 million, including some entertainment at the end of 2009, hire experts, select the project plan, the municipal government's opinion, and on the preparation of the project, it was spent nearly eight million. In the phase of the project, real estate was completed in May 2011, and in December 2011, it began to be put into use, including a large number of office buildings, acommercial plaza, family homes.

This will be the time to begin a gradual recovery of the funds. LanzhouYatai Group real estate project on the average time from starts to recovering funds up to 3-5 years. These data also show that the use of return on investment to raise funds needs to design a lot of products on the market, such as building materials market, financial markets, such as participation in the talent market funds. Mixing these markets also further increases the real estate market made hybrid and raising funds intermediation cycle becomes longer.

\subsection{Value-added Funds}

With starting building Lanzhou rail traffic, most people would consider the purchasing of their homes which are not far from the subway station. Rail Transit Line 1 invested in early 2014 has begun in the government's strong support for the construction of the second phase in which line one will also be extended to the Lanzhou New Area in 2020, and it is located at the intersection of the suburban railway station Airport Expressway only 100 meters from the Yatai headquarters base. These conditions are certainly convenient transportation facilities for the development of real estate projects in Yatai Group, so Lanzhou Area laid a huge value-added space.

It is coupled with the light rail project and also makes the city from the new district to shorten the time from the original 1.5 hours to 25 minutes. But it also fully embodies the public to Lanzhou New buyers convenience. Therefore, Yatai Group in the business and financial circles gradually joined the ranks of the team, and it will be followed by a more value-added real estate funds.

\subsection{REITS Financing of Yatai Group}

This method is similar to a mutual fund, so it takes the form of a trust company or business organization to issue revenue certificates. Thus, multiple investors raise funds, and professional investment institutions manage them in various ways to invest in real estate projects. A new real estate trust financing system has great advantages. It only involves the construction of real estate investment companies and other investment. Therefore,trust fund is not the same, and in recent years, it supports the healthy development of the Yatai Group Rose Garden project. Currently, under the macro-control policy, Lanzhou Yatai Group isalso gradually mature to adopt this way of financing, and trust 
circulation gradually increased. Usually, it is in the financing process. In the following there are three mainly common financing models shown in table two.

After 2010, Yatai Group in the context of the country's economic macro-control started using this financing model. Through the statistical data from the perspective of Yatai Securities Department, REITS senior management team under the leadership of chairman, Zhu Quanzu, has raised 175 million RMB of funds according to the characteristics of the project on the Rose Garden project. Yatai Group on financial supervision are concerned, and trust funds and equity loan category can absorb direct investment trusts to reduce the risk of bank credit effectively.

Table 2: Three Modes of REIT Financing of Yatai Group

\begin{tabular}{|l|l|}
\hline \multicolumn{1}{|c|}{ Mode } & \multicolumn{1}{|c|}{ Features } \\
\hline $\begin{array}{l}\text { Capital Trust Loan } \\
\text { Category }\end{array}$ & $\begin{array}{l}\text { This mode is similar to traditional bank loans. However, funding patterns are different. } \\
\text { Capital trust fund loan category opens from issuance trust scheme. }\end{array}$ \\
\hline Equity Trust & $\begin{array}{l}\text { It refers to the unique housing prices which are repurchasing a stake in equity financing } \\
\text { mode. This financing model is not only to meet the financing needs of the Asia Pacific } \\
\text { Group but also improve the company's credit rating. Making the overall capital structure } \\
\text { of the company is optimized. Performance without increasing asset-liability ratio of the } \\
\text { situation increases the real estate business capital. }\end{array}$ \\
\hline $\begin{array}{l}\text { The Transfer of the } \\
\text { Interest }\end{array}$ & Beneficial \\
\hline
\end{tabular}

Source: Authors construction

\section{Problems and Causes of Traditional Financing of Yatai Group}

Traditional financing forms the basis for the company's early development, but except few above described common current way of financing, a small business was also applied to some financing working capital debt financing, venture capital, mezzanine financing. Generally speaking, when used together, these financing reduces the risk of corporate finance, but sometimes the choice of various financing will be a certain percentage of disharmony or an over-reliance on a particular financing channels. In the absence of financing, the system of early warning mechanisms should be cautious about company found problems.

\subsection{Problems of Reasonable Financing Structures}

Yatai Group real estate project financing structure will be different because of the division of corporate capital and different ways. It will be shown in table three.

Table 3: Real Estate Project Financing Structure Parameter Table

\begin{tabular}{|l|l|}
\hline \multicolumn{1}{|c|}{ Division of Financing } & Parameter Ratio of Financing Structure \\
\hline According to Different Ways of Funding Sources & $\begin{array}{l}\text { The proportion of internal and external sources of } \\
\text { financing is } 69 \% .\end{array}$ \\
\hline According to Different Long Term and Short Term Capital & The proportion of Long-Short term Financing is $93 \%$. \\
\hline According to the Division of Funds in Different Ownership & The proportion of equity capital and liabilities is $87 \%$. \\
\hline
\end{tabular}

Source: Report of the First Quarter 2013: http://www.ythouse.com.cn/show.asp?id=1426

From Yatai Group financial statements from 2011 to 2013, the average debt ratio is up to $87 \%$ which can be seen that the pressure is already very large, and debt is significantly higher than shareholders' equity. The ratio of internal financing and external financing reached $69 \%$, and it shows that the proportion of outside financing is much higher than the source of inside financing, and corporate financing costs are increasing year by year. Long-term financing and shortterm financing ratio reached $93 \%$ and totally reached 170 million RMB. 
The financing structure can be seen from property ownership and financing risks, such as some of the features. It reflects the pressure on corporate financing unabated. If companies continue to use the previous financing, the ratio will be high debt ratio. The phenomenon makes the financing structure distortions appear. Therefore, a reasonable structure is a serious problem in conventional financing.

\subsection{The Lack of Early Warning Mechanism for Financing Risk}

Yatai Group is a capital-intensive industry. In the operation process of real estate projects in more urgent need for capital, the risk of the project financing is the group need to focus on financing targets, but it also becomes the object of prevention. Balance Sheet on June 2012 (Securities Department) in the first half year shows the company's bank loans have reached 260 million RMB. (80 million from China Merchants Bank, 120 million from Shanghai Pudong Development Bank, 40 million from Industrial and Commercial Bank of China, 20 million from the rest of the bank).

Due to some reasonable use of the real estate trust, the company gradually reduces the number of bank loans within three years. However, by 2011 Yatai Group remains widespread attention focused on the pursuit of profit concern for risk prevention and early warning efforts are small. Therefore, enterprises should improve the financing risk warning mechanism.

\subsection{Over-Reliance on Bank}

Yatai Group at the time of start-up is only a very small real estate company. With the increase in business it is gradually developing into a large, publicly traded real estate company with a total construction area of more than 400 million square meters, and awards of "China Famous 100" and "China Real Estate Top 50 famous enterprises" and other awards; recent years, "Yatai • City Moonlight", "East Yatai and Yatai • Constellation" are about to complete the development and construction.

But in the early stages due to excessive reliance on bank loans, the company has been defeated some difficulties in financing situation in the 2009 financial crisis through this most direct financing channels. And Gansu underdeveloped regional government also controls the Lanzhou soaring housing prices which did not fall as an unprecedented slump. So in 2010, the company entered the bottleneck stage in a slow development.

\section{Financing Mode Design of Yatai Group Real Estate Project}

The author believes traditional financing within a certain time would be replaced by financing part of the project. Financing models will be combined with traditional financing and project financing. According to the special nature and characteristics of project finance real estate projects in Yatai Group, this chapter is suitable for the development of real estate projects in Yatai Group's financing model, and it is suitable for the development of Yatai Group project financing mode in-depth analysis and discussion.

\subsection{Significance of Yatai Group Real Estate Project Financing Mode Selection}

Financing behind the company has paid a high cost of capital as the price. At this point, the Group Finance Department has indicated that the current debt ratio to Group headquarters has been at a high level. A rapid increase will be in the cost of capital if it will bring the debt ratio increased.According to the trade-off theory and financial leverage, it was coupled with land reserves leading to along-term lack of funding sources.

On the above analysis of Yatai Group, the group should now be considered an appropriate way to improve project financing and financing efficiency. So, from the above analysis, the traditional financing methods are hard to meet the high efficiency of the financing, but also hindered Yatai Group further development.

\subsection{Factors of Yatai Group Real Estate Project Financing Model Design}

\subsubsection{National Policy}

In recent years, not only the national macro-control policies continues to strengthen financial policy and land policy, but also from the administrative, tax and other aspects of the real estate industry is under macro-control. From Gansu Province in recent years, the trend of macro-control is in the point of view, and it is also from the macro to the general 
micro trend. Local government macro-control of the real estate industry to take its starting point is to stabilize the people's livelihood, stable prices, but also to stabilize Gansu Province real estate financial markets.

However, due to a series of macro-control and monetary policies on the real estate development, our company created a relatively strong impact, even in the short term there is no impact on the real estate, but in a period after an impact it is on the further development of real estate. From 2012 to 2013, the average housing price of Lanzhou was from 8500 $\mathrm{RMB}$ / square meter falling to $7800 \mathrm{RMB}$ / square meter. However, not all of the housing prices at this time will be subject to the impact of these policies.

Some well-funded real estate companies can still borrow some money and take advantage of loopholes and gaps policy control through small acquisitions of aweaker company growing their strength. As for Yatai Group, it was affected by fluctuations in the capital market, stock ups, and downs. In the year 2013 falling 14.96 points from the highest to the lowest point of 6.95 .

\subsubsection{Interest Rates}

In 2009, the hot real estate situation made the whole industry a big demand for funds, as well as to reach a peak. But from the beginning of the year before last March, due to the central macro-control policy, making tightening credit policy and raised the bank deposit reserve ratio are a clear trend in the real estate market declining. Interest cost is defined as the use of funds in the financial science. Because of the higher level of interest rates, companies will need to pay interest on the higher cost of doing business, so its financing costs will rise as well.

Conversely, if interest rates are too low, the banks and other financial institutions will lose a source of profit. So some real estate financing initiative of financial institutions will be affected by both situations. And the level of interest rates will also have animpact on the residents, thus affecting the ability of consumers to pay the loan and repayment pressures confidence. Thus, the interest rate lever can effectively control the bad real estate market development trend and prompt real estate companies to seek more funding and open up wider financing channels.

\subsubsection{Soundness of the Financial System}

Safety of the financial system for financing the external environment plays a very crucial role. The CentralBank is important to commercial banks and financial institutions. Real estate and efficiency of financial factors affecting the real estate development will become key factors, such as the degree of perfection of thereal estate financial system, regulating the level of development of real estate and financial markets, the implementation of monetary policy. Yatai Group relies on good reputation and leads theposition in Gansu Province. Gansu, real estate sector, is in obtaining bank loans, but the financial system is not perfect in less developed western regions of the financial system. They are still not perfect real estate project financing channels.

\subsubsection{The Cost of Capital Financing}

The most direct factor of Yatai real estate financing behavior is the cost of capital. Therefore, regarding theexogenous type of financing, bank loans are low-cost and relatively stable as a means of financing. However, project financing and financing costs also determine the effect of financing enterprises. Such costs can also be used to some extent. In the face of a different mode, financing companies to choose a project financing is bound to give up the rest of the project financing mode. Because project financing will also face certain risks and difficulties, uncertainty and cost of financing will result in an absolute impact on the results of financing. By this time some investment experts and technical staff of the prediction and assessment of project financing will select the highest expected rate of return to minimize the cost of a model.

\subsubsection{Size of the Business and Brand}

In 2012, group board of directors declared that the enterprise development within a decade would become the first international company in Northwest China. Yatai Group should measure their advantages and characteristics to increase the attractiveness of the provider. The funds should be considered in different financing model for enterprises to raise the required amount of capital financing, financing costs, and the impact of time. High-quality, low-cost financing to fund the traditional financing channels was represented in the stock market only to meet the diverse needs of financing in which a small part of the funds are in Yatai Group. In the past financing within a few years, the number 
is gradually increasing. In determining the validity of the policy of some real estate financing, the Group's project investor should also consider the time and flexibility needed financing process.

\subsection{Yatai Group Real Estate Project Financing SWOT Analysis}

From a view of the concept of competitive strategy, competitive strategy renowned innovative departure from the company's proposed strategic SWOT analysis. This combination of factors analysis of internal and external aspects of the enterprise reflects enterprise's strengths and weaknesses, corporate external opportunities and threats in these areas to analyze the company's direction and strategy. While the enterprise is in the development, SWOT analysis is still a practical analysis method. According to YataiGroup, the author figures out the company's internal conditions and external environment. The following table four is Yatai Group SWOT analysis of the real estate project financing.

Table 4: Lanzhou Yatai Group SWOT Analysis of Real Estate Project Financing

\begin{tabular}{|c|c|c|c|}
\hline S-Strength & W-Weakness & O-Opportunity & T-Threat \\
\hline $\begin{array}{l}\text { After1997, it has been the } \\
\text { first listed real estate } \\
\text { companies in Gansu } \\
\text { Province, and its brands } \\
\text { have obvious advantages } \\
\text { which are easy to carry out } \\
\text { more development projects. }\end{array}$ & $\begin{array}{l}\text { The mortgage is very } \\
\text { cumbersome. At the } \\
\text { same time, and } \\
\text { operation of the project } \\
\text { period is longer through } \\
\text { large capital investment. }\end{array}$ & $\begin{array}{l}\text { New construction of Lanzhou } \\
\text { absorbed much national attention, } \\
\text { and national leaders have } \\
\text { attached great importance to the } \\
\text { construction and development as } \\
\text { the fifth national economic } \\
\text { development zone in Lanzhou } \\
\text { New Area. }\end{array}$ & $\begin{array}{l}\text { Local banks or financial } \\
\text { industry developed, and lead } \\
\text { to the traditional financing } \\
\text { channels to be sluggish, } \\
\text { inefficient. Therefore, it } \\
\text { slightly impedes the rapid } \\
\text { development of project } \\
\text { financing. }\end{array}$ \\
\hline $\begin{array}{l}\text { Dedicated management } \\
\text { personnel are at all levels, } \\
\text { and laid the foundation for } \\
\text { the strategic development of } \\
\text { the company. So the } \\
\text { preliminary work on the } \\
\text { project financing is more } \\
\text { fully prepared. }\end{array}$ & $\begin{array}{l}\text { Some } \\
\text { sometimes employees } \\
\text { some materials data, } \\
\text { thereby kickbacks from } \\
\text { construction materials } \\
\text { inside. }\end{array}$ & $\begin{array}{l}\text { Lanzhou Rail Transit Line one } \\
\text { phase II project in } 2020 \text { will lead } \\
\text { to the Lanzhou new Area because } \\
\text { Yatai Group headquarters will be } \\
\text { helpful to Lanzhou new } \\
\text { technology district development. }\end{array}$ & $\begin{array}{l}\text { Some large factories and } \\
\text { enterprises gradually migrate } \\
\text { to Lanzhou Area, so that } \\
\text { these companies can } \\
\text { complete projects here as } \\
\text { well. So it brings competitors } \\
\text { to Yatai Group. }\end{array}$ \\
\hline $\begin{array}{l}\text { "Yatai } \\
\text { Residence" } \text { International } \\
\text { Chinese the 50 } \\
\text { communities. Therefore, it } \\
\text { helps to attract more } \\
\text { businesses to invest and } \\
\text { settle down. }\end{array}$ & $\begin{array}{|lr|}\text { Human } & \text { resource } \\
\text { allocation } & \text { is } \\
\text { unreasonable. } & \\
\text { Cooperation } & \text { between } \\
\text { employees } & \text { and } \\
\text { leadership do not } \\
\text { understand each other. }\end{array}$ & $\begin{array}{l}\text { The city's light rail project will be } \\
\text { complete before 2016, which } \\
\text { makes more and more citizens } \\
\text { buy ahouse in the new district. }\end{array}$ & $\begin{array}{l}\text { National regulation of real } \\
\text { estate will continue, as well } \\
\text { as tight control policy trends. } \\
\text { So the government } \\
\text { intervention in the financial } \\
\text { markets is frequent. }\end{array}$ \\
\hline
\end{tabular}

Source: Authors construction

From the SWOT analysis above we can see the advantages and disadvantages of Yatai Group real estate project financing, also internal strengths and weaknesses. This analysis obviously lists these positive and negative factors. But money is necessary from the perspective of businessregarding corporate finance. Only in a short time to rise the number of lower-cost business is meant success. Through the above analysis and summary, we seem to have seen the traditional financing channels gradually become more and more narrow. Also in 2013 Wanda Group will be settle in Lanzhou to compete with Yatai Group, so Lanzhou gradually become more intense, opportunities and challenges coexist. So we need more effectively to carry out deeper discussion of Yatai Group project financing. 


\subsection{Yatai Group Real Estate Project Financing Mode}

\subsubsection{Sale-Leaseback Financing Model}

Yatai Group on some real estate business process used this model to increase the amount of financing. It used asset once again after the sale, then leaseback the asset from the purchaser's hands, such as the Yatai mobile phone Lanzhou Guang $\mathrm{Wu}$ Men hypermarkets, Lanzhou Zhongshan Road, New Oriental English School campus. These are my company's success leaseback typical case. So I think that Yatai Group can continue to use the asset not only in this way, but you can get money to the asset realized. This sale-leaseback of project financing model significantly improves the efficiency of Yatai Group financing, while authors believe that this leaseback can still be practical and widely used in some projects in Lanzhou Area.

Its main operational processes to operate are through the following steps: (1) In the real estate project company after a good pre-sale estimate of housing rents and prices, it ensures ahigh rate of return on interest rates on bank deposits above the pre-sale estimate of real estate projects ROI. (2) In Yatai Group and the project company to complete the necessary real estate purchase signed contract, the project must be by the agreed sale and leaseback of these properties again. (3) In the project company, it leased property during the processing of users, and monthly rent must be used to pay the landlord. At this point,Yatai Group has sold the property to recover the backlog cost, so not only it can complete the sale and leaseback, but also can gradually solve some of the project's financing problems, such as shortterm financing gap. And for a lot of buyers and property purchased already, the company can avoid bankruptcy suffered unnecessary losses due to the project.

\subsubsection{The 'Delivery' as the Basis of the Financing Model}

This financing model is based on expected sales of all purchase loans from banks, financial intermediaries project, part of the product or rental income over equity. In the late 1970s in some countries in North America, solar, wind, geothermal and other project financing are derived. Listed companies are often able to compare accurately calculation from the annual statement. (Securities Department, Finance Department report shows per year). Therefore, Yatai Group financing model will not only improve the return on assets, and financial intermediaries will receive advance funds or bank financing in advance to reduce the risk.

This financing model is based entirely on the lending bank to buy the company or part of the revenue base over the interests of future sales. Yatai Group was building land 170 million RMB investment in the new project in Lanzhou Area. Company executives have decided to build $20 \%$ of the land area for office or financial institutions.

Most banks will be designed to the same specification on the floor or lower floors of residential buildings. In recent years, more commercial banks enter to Lanzhou. (2013 Industrial Bank, Ming Sheng Bank 2014) So this financing model can also be used to consider this point. Also under this project financing mode of operation, the bank will provide loan funds to buy shares from the project specific products, and these products revenue share of project financing will become the main source of funds. At this time the bank will loan direct ownership of the usufruct project products so that you can get extra profit. About the gradual appreciation of these fixed assets, it is not necessary to achieve credit secured financing through a variety of ways to transfer or mortgage equity.

This financing model has the following characteristics: First, real estate companies and lenders through this mode are constructed a "financial intermediary" platform. Secondly, about afinancial institution or bank check before the development of real estate projects, it will be paid to the investment company based on contracted projects to ensure the project schedule. Thirdly, in the real estate company's real estate projects in the sales phase, the project company as a financial intermediary will be based on sales agency agreement to sell the real estate agent, and the financial institution or a bank can also get a commission through the intermediary of real estate to expand their strength. This makes the real estate finance system more closely. 


\title{
6. Optimized Design and Implementation of Yatai Group Real Estate Project Financing Mode
}

\author{
6.1. Management Objectives of Optimized Project Financing Mode \\ Based on the macro and micro levels, the goal of risk management is a clear distinction.
}

\subsection{Macro Risk Management Objectives}

From the perspective of financial markets, macro-financial risks goal is to maintain the stability of the entire financial market, to avoid financial market turbulence. While maintaining the stability of the financial market's confidence in the country's financial system, it promotes efficient development of financial markets orderly and promotes regional economic of Gansu Province. When a country's macro-stability objective of financial risk management is required to achieve basic standards, the ultimate goal of financial risk management is to reduce as much as possible to avoid the risk of economic loss avoided by economic agents. Maintaining financial system stability and development is a basic requirement management, so financial risk management should be reported to the attitude of continuous improvement and ultimately financial order and the continuous optimization of resources.

\subsection{Micro Risk Management Objectives}

About the pursuit of profit maximization, financial risk management is to aim to minimize the risk of loss. That is to ensure the integrity of the proceeds as possible. However, in some cases, there is a contradiction between the two. When the Group companies only focus on the pursuit of profits before ignoring synchronization prevention of risks, the direct purpose of financial risk management is to reduce getting interests with the overall objective of economic agents relative. Also, due to the financial risk management objectives, it will inevitably require adjustment. Two contradictory goals need to seek to maximize the interests of prudent risk prevention. Also in Yatai Group project in 2016, the first phase of construction of new district should pay their bills, and this still needs enough money to improve things. But the main purpose is to increase the group's estate value of the business, thereby increasing the wealth of the owner and expanding the business.

\subsection{Optimization Principles of Yatai Group Real Estate Financing Models}

For the actual situation of Yatai Real Estate Group, in a real estate project operation process, a variety of financing do not exist in isolation. It often requires a combination of traditional financing and project financing, and therefore, in Yatai Real Estate Group, you can spread the risk of certain financing. At first, the source of financing and external financing principles seen in the financial analysis is much higher than the total amount of endogenous financing. Furthermore, it is a traditional financing structure optimization principle, as well as traditional financing with a combination of project financing.

At last, before the Real Estate Group established a practical way of financing, they have to be sure of the issue of financing costs. For Yatai Group, the cost of financing refers to some cost of corporate financing in the course of business. In Yatai Group's overall view, because the type of items can be used in new financing channels range, some of the previous traditional financing packages also includes two new proposed models of project financing. However, no matter what form the results of financing options have, an objective evaluation and judgment should optimize the entire Group's capital (financing) structure. So we need to calculate the weighted cost of comprehensive channel model under various funding sources.

\subsection{Optimized Measures of Yatai Real Estate Group Investment Fund Financing Models}

For the current financial regulatory policy and some large real estate case studies, Yatai Real Estate Group as top 10 companies in Gansu Province should also develop real estate investment funds.

By the characteristics and nature of real estate investment trusts, we identified some properties of this financing highefficient and low-risk. This financing way to get good results in the past few years is in the use of Yatai Group getting 20 million funding in 2011. Thereby sharing the risk of financing has some other channels. The author believes this approach can meet the financing of Lanzhou Yatai Group of financing because it is combined with the use of project 
financing. This is concretely the better operating system. REITs can be improved to some extent. Yatai Group capital structure can reduce the cost of business-related financial risk and financing.

And more importantly, one can also get an additional discount of the high real estate prices and the right priority to purchase real estate, so investors at this time will give the principal at a lower capital cost. We can make even trust loan interest rates lower than the bank interest rates. Thereby, increasing the customer's investment in Yatai Group makes full use of investment trusts. To develop real estate projects in Yatai Group to raise large amounts of external funding, while addressing the development and operation of real estate projects in the process of financing shortage problem. By real estate investment trust fund to carry out, effective operations also can absorb large amounts of private lending capital, and ultimately the real estate investment trust come into the Yatai Group as an important financing channel.

\subsection{Optimization Measures in Various Stages of Financing Development}

When Yatai Group made a selling permitting to enter the sales stage in June 2012, it has become major source funds of Yatai group, which is not only for enterprise developers, but also conducive to the timely repayment of project funds. Marking the beginning of the project is to enter the profitable stage, and this time, it pays a progress payment and selling expenses. This phase of sales for the supply of funds also have a key role, such as the sale and leaseback, underwriting and other sales model. Through table five description of Yatai Group, the selection and the ratio of the cost of capital at every stage will be indicators of project development financing mode.

Obviously, we can see that the first phase of operation of the project in the whole process in 2012, and the cost of capital financing rates show a gradual downward trend. Because some of the macro-control policies are in recent years, the development of four cards before the project is complete before funds enter some financing channels. With the establishment of the progress, there will be a new project as well as the headquarters of Lanzhou Yatai New Technology Area. Project development funding needs are affected as little as possible to national and local financial policies of Lanzhou City, while the cost of capital has been effectively reduced.

Table 5: Financing Cost of Capital in Yatai New Projects at Different Stages

\begin{tabular}{|l|c|l|}
\hline Different Stages of Financing Costs & Financing & Cost of funds \\
\hline Obtain Building Land Qualification Stage & Equity financing and public financing & $14 \%-22 \%$ \\
\hline Obtain the Construction Permit Stage & Trust & $12 \%-18 \%$ \\
\cline { 2 - 3 } & Fund & $10 \%-14 \%$ \\
\hline Development for Marketing Stage & Engineering Loaning and Bank Loans & $7 \%-8 \%$ \\
\hline
\end{tabular}

\section{Conclusion}

In recent years, financing decisions have been in the real estate business which is good for sustainable development as key factors. So, naturally, financing has become the company's most important issue in the real estate industry. The problem is that real estate corporate finance, insurance, real estate and other related industries are in a system. Unity of the real estate financing channels for enterprises and other issues is mainly in the business of traditional financing channels. Coming to an end at the time of this article combined with Yatai Group real estate project financing channels for optimization problems, the financing of basic theory and empirical research are combined with the social background which exists in the real estate business.

Through a series of problems in the real estate financing model of Yatai Group, we proposed the implementation of policies and strategies to protect innovative real estate project financing selection optimization model and the new financing program. We believe that the financial institutions, real estate development companies, and the government should actively strive to take advantage of the national policy to build a better Yatai Group. At the same time, financial institutions should speed up innovation of financial products and improve the system construction, which will effectively promote Lanzhou Yatai Group to maximize the use of value for money and to choose the best combination for their development needs in financing mode. It will gradually increase in the rapid development of the real estate industry projects in Lanzhou New Area, so as to promote the sustainable and healthy development of the local economy. 


\section{Acknowledgments}

We would like to thank professors Guoxing Zhang, who helps proof reading the article. We also want to thank the anonymous referees as well as the editors.

\section{References}

- Chan A P C, Scott D, Lam E W M. Framework of success criteria for design/build projects [J]. Journal of Management in Engineering, 2002, 18(3): 120-128, CrossRef

- Pheng L S, Leong C H Y. Cross-cultural project management for international construction in China [J]. International Journal of Project Management, 2000, 18(5): 307-316, CrossRef

- Deng Z M, Li H, Tam C M, et al. An application of the Internet-based project management system [J]. Automationinconstruction, 2001, 10(2): 239-246, CrossRef

- Shen L Y. Project risk management in Hong Kong [J]. International Journal of Project Management, 1997, 15(2): 101-105, CrossRef

- Chan A P C, Scott D, Chan A P L. Factors affecting the success of a construction project [J]. Journal of construction engineering and management, 2004, 130(1): 153-155, $\underline{\text { CrossRef }}$

- Chan A P C, Ho D C K, Tam C M. Design and build project success factors: multivariate analysis [J]. Journal of construction engineering and management, 2001, 127(2): 93-100, CrossRef

- Veale P R. Managing corporate real estate assets: current executive attitudes and prospects for an emergent management discipline [J]. Journal of Real Estate Research, 1989, 4(3): 1-22. [8] Ginevičius R, Zubrecovas V. Selection of the optimal real estate investment project basing on multiple criteria evaluation using stochastic dimensions [J]. Journal of Business Economics and Management, 2009 (3): 261-270.

- Krumm P J M M, Dewulf G, De Jonge H. Managing key resources and capabilities: pinpointing the added value of corporate real estate management [J]. Facilities, 1998, 16(12/13): 372-379, CrossRef

- Steinfeld E. Chinese enterprise development and the challenge of global integration [J]. Global production networking and technological change in East Asia, 2004: 255-96.

- Anderson A R, Li J H, Harrison R T, et al. The increasing role of small business in the Chinese economy [J]. Journal of Small Business Management, 2003, 41(3): 310-316, CrossRef

- Gibb A, Li J. Organizing for enterprise in China: what can we learn from the Chinese micro, small, and medium enterprise development experience [J]. Futures, 2003, 35(4): 403-421, CrossRef

- Chen W. Does the colour of the cat matter? The red hat strategy in China's private enterprises [J]. Management and Organization Review, 2007, 3(1): 55-80, CrossRef

- Zhonghui W. Private enterprise in China: an overview [J]. The Journal of Communist Studies and Transition Politics, 1990, 6(3): 83-98, CrossRef

- Tian G. Property rights and the nature of Chinese collective enterprises [J]. Journal of Comparative Economics, 2000, 28(2): 247-268, CrossRef 